\title{
BREEDING Virescens OIL PALM
}

\section{VENGETA RAO* and CHANG, K C**}

\begin{abstract}
Recent discoveries of five independent but closely related nucleotide mutations that result in the virescens fruit type in oil palm, and their diagnostic markers, have renewed interest to breed for the trait. In virescens palms, the immature fruits are green, ripening to a bright orange, whereas in the common nigrescens palms, the immature fruits are a deep purple, almost black, and ripen to red with purple tinges. Ripe virescens bunches are more easily spotted, especially at distance and through the lower fronds and epiphytes on the trunk, thus having fewer missed in harvesting. Correspondingly, unripe and under-ripe virescens fruit bunches would be apparent, compared to their nigrescens counterparts, during fruit milling. While diagnostic markers will improve the breeding efficiency and save on time and costs, starting with the right virescens palms will ensure that the trait is not gained at the expense of yield.
\end{abstract}

Keywords: oil palm, breeding, virescens, nigrescens, ripening, milling.

Received: 7 January 2020; Accepted: 12 July 2020; Published online:

\section{INTRODUCTION}

There are two fruit colour types in the African oil palm (Elaeis guineensis) - the usual nigrescens and the much rarer virescens. In nigrescens (Latin for black), the unripe fruits are a deep-violet, seeming black, ripening to red with some residual violet in the apical and cheek regions. In virescens (Latin for green), the fully green young fruits ripen to a bright orange with just a little green on the apex (Figure 1). Virescens just lack the epicarp anthocyanins and other flavonoids (hence, the absence of dark colours) and have no other known differences with nigrescens, for example, higher/lower yield or oil quality. While the ripening skin colour change in nigrescens results from the degradation of anthocyanins and other flavanoids (Hazir et al., 2012) and chlorophyll (Ikemefuna and Adamson, 1984) (the underlying red coming through these diminishing masking colours), it is largely the degradation of chlorophyll in virescens and the underlying orange coming through, especially with

\footnotetext{
* Lot 6729, Jalan Batu Satu,

43800 Dengkil, Selangor, Malaysia.

E-mail: vengetarao@gmail.com

** 111, Jalan 12/14,

46200 Petaling Jaya, Selangor, Malaysia.
}

the accumulation of carotenoids in the mesocarp (Hortensteiner and Krautler, 2011). As the colour change is gradual, bunches of intermediate colours may be found on the same palm. Though less obvious, intermediate colours may also be discerned in the fruits of the same bunch, reflecting their differences in development from a common pollination time, for example, green parthenocarpic fruits in an otherwise bright orange ripe virescens bunch (Figure 2).

The evolutionary implication(s) for the colour difference is unknown as both types seem equally attractive to dispersal agents, such as birds and small mammals, nor have any advantage/ disadvantage from biotic or abiotic pressures. Logically, virescens should occur more, perhaps even exceed nigrescens in some locations. This is because it is genetically dominant over nigrescens and, while virescens mutations are rare (see next section), over an evolutionary period of 6-51 Mya (Ergo, 1997; Singh et al., 2013) and with clear human preference for it, it would have, arguably, overtaken nigrescens, at least in some locations. So, its continued rarity suggests some unknown factor(s) culling it, possibly anthocyanins affording nigrescens some protection. But this is entirely speculative as also the suggestion that the mutations may be all very recent (Rao, 1987). 


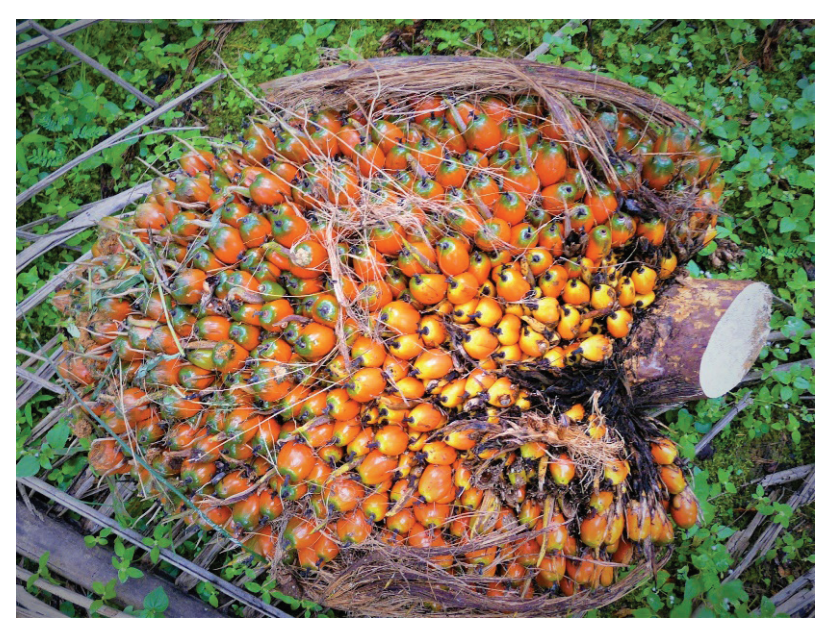

Figure 1. Ripe virescens bunch showing orange fruits with halos of green at the apex, pale yellow where less exposed to the sun.

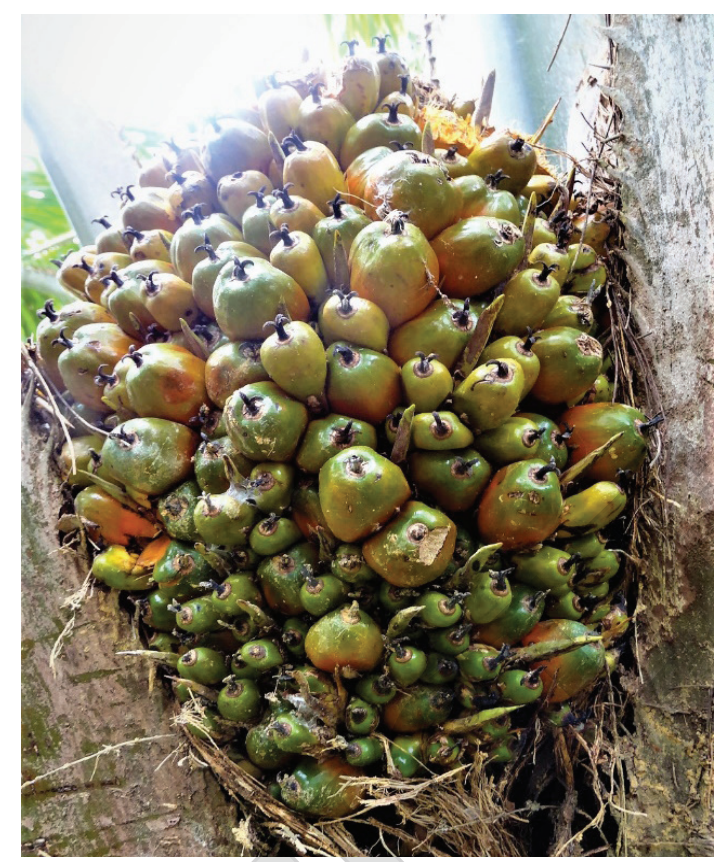

Figure 2. Ripening virescens bunch showing fruits of intermediate colours and green parthenocarpic fruits.

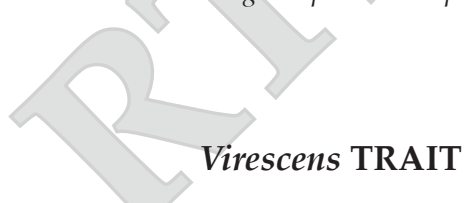

Rao (1998) observed fruit and bunch ripening in virescens palms. The bunches are green until about two to three weeks before the onset of fruit abscission. Then the colour rapidly changes to brass/bronzegreen, then to brass/bronze-orange, to increasingly orange and, finally to a bright reddish-orange. In a palm, bunches of all the above colours may be seen, reflecting their different ages. To a smaller extent, the colour gradation also occurs in the individual fruits of a bunch reflecting the small differences in development despite their near-simultaneous pollination.
Oil accumulation occurs with the colour change but the rapid increase in the final weeks is when the fruit is already largely orange. The accumulation is complete just before or at first fruit abscission. Hence, while bunches that are mostly orange may already have much oil, the maximum is only reached at incipient fruit abscission. In other words, for maximal oil the indicator for when to harvest ripe bunches can still be the normal nigrescens standard of counting loose fruits. This detracts somewhat from the appeal of virescens, but the trait is nevertheless still useful as the harvester is more likely to miss darker bunches in the darker recesses of the palms at height. It will be even more important when the loose fruit standard cannot be followed, for example, when harvesting labour is short or during the monsoon floods. Also, virescens will avoid the harvesting conundrum from 'physiological ripening' where young bunches with little oil drop fruits from softened, watery ends, the causes of which are still unknown.

In the virescens fruit, the colour change is acropetal (from base to top). In the bunch, the colour change is also acropetal, with fruits in the bottom spikelets leading the way, following the also acropetal flower anthesis. However, in many bunches, this acropetal pattern is obviated by other influences and no pattern is obvious. As abscission of the ripe fruits commences when most of them are still brass/bronze (not yet orange), the development of more-uniform ripening palms is key. This trait is more readily scored in virescens than nigrescens, and can be done in the bunch analysis laboratory.

Like in nigrescens, unexposed (to light) fruits or parts of them in virescens are a lighter hue pale cream when young, with an orange tinge on ripening. Parthenocarpic fruits are less bright and their change in colour slower. This is also influenced by the extent of parthenocarpy in the spikelet/ bunch - the more parthenocarpy, the slower the development and colour change. This slower colour change is, in fact, a good visual indicator of the pollination. If the harvested bunch is largely orange but with many interspersed green fruits, then the pollination is poor. Where there is an extensive pollination problem, in young or some clonal fields, for example, the overall bunch colour may be arbiter of whether to send it for milling or discard.

Rao (1998) also observed that harvested underripe bunches continue their colour change, and this may be temptation to 'age' them to 'full' ripeness, but the oil will not increase.

\section{Genetics}

Early work in Congo and Nigeria suggested that a single dominant gene causes virescens. In Congo, a virescens palm gave $75 \%$ virescens in its selfs while out-crossing to nigrescens gave $50 \%$ each of virescens 
and nigrescens (Beirnaert and Vanderweyen, 1941). Hartley (1988) reported that in Nigeria an openpollinated virescens bunch gave $46 \%$ virescens (and $54 \%$ nigrescens) and nine virescens $\mathrm{x}$ nigrescens crosses gave $54 \%$ virescens and $46 \%$ nigrescens, that is, about 50:50. He also made the interesting observation that in virescens the absence of anthocyanins (of which there are several types) is not absolute, with traces of one/some which may be distinct from those in nigrescens.

Singh et al. (2014) discovered that mutations of the (Vir) gene render it dysfunctional for anthocyanin biosynthesis, that is, they cause virescens. Three single nucleotide mutations, a deletion and a nucleotide rearrangement, collectively accounted for $99 \%$ of the virescens phenotypes, but the $1 \%$ discordance suggests that there may be yet other mutations or mechanisms. The small discordance is, however, academic for practical virescens breeding which can now be much more efficient. Furthermore, as mutations of the Vir and Shell gene are independent, virescens can occur in duras, teneras and pisiferas. Hence, good virescens DxP can be produced from an elite homozygous Vir pisifera through conventional breeding aided by the genotyping tools.

The mutations occur very rarely, as evidenced by the low frequency of virescens found - 0\%-3\% in Ivory Coast (Meunier, 1969), $0.5 \%$ and $0.7 \%$ in Nigeria and Angola, respectively (Hartley, 1988), and $6 \%$ and $0.7 \%$ in Cameroons and Zaire (now known as the Democratic Republic of Congo), respectively (Rajanaidu, 1986). Similarly, amongst the millions of cultivated oil palm in South-east Asia, only an occasional virescens is seen, presumably not from the sources of planting materials. The low frequency also implies that most of the mutations are in the heterozygous state.

The frequencies are higher with human interference, for example, the $6 \%$ in Cameroons above is an average from about 2000 wild palms in 11 sites, spiked by two more cared - for sites with $18 \%$ and $36 \%$. In many parts of Africa, the 'red palm fruit', or Akwu Ojukwu, is revered, its oil and kernel believed to cure ailments and ward off evil (Eziokwu Chineke Gadi, 2017), valued as an anti-poison and miracle oil in Igboland traditional medicine (Ogbuanu et al., 2015) and a general treatment for illness in rural Benin (Akpo et al., 2012), etc. Perhaps, as in humans, redheads are preferable to blackheads, even without any lore of the occult, simply because they are more exotic.

\section{Usefulness of Virescens Trait}

The most cited use for the trait is as a cue for bunch ripeness, to tell when to harvest it. The colour change with ripening is more distinct in virescens than in nigrescens, making ripe bunches easier to spot, particularly in tall palms, through the maze of lower fronds and axillary epiphytes on the trunk. Similarly, ripeness needs to be gauged in the FFB (fresh fruit bunches) landed at the palm oil mill to decide on which to process/discard. With ripeness being the most important determinant of oil extraction rates, the economic implication of accurately determining it is substantial. The traditional method is to sight a specified number of abscissed, or 'loose', fruits fallen from the ripening bunch. But, interest in mechanised harvesting with increasing worker shortage, is veering it to more automated assessment, particularly vision- or image-based.

Real-time automated assessments, from which mechanical segregation can be effected, may be even more feasible in the palm oil mill. Some exploratory work on automated assessments can be found in Abdullah et al. (2001), Alfatni et al. (2008; 2014), Junkwon et al. (2009), Tan et al. (2010), Roseleena et al. (2011), Hazir et al. (2012), Saeed et al. (2012), Bensaeed et al. (2014), Cherie et al. (2015) and Utom et al. (2018).

The discovery of non-abscinding/non-oil palm (Donough et al., 1995) offered hope for needing less of the laborious and costly manual loose fruit picking off the ground. But the counting of dropped/loose fruits from ripening bunches is now the criterion for harvesting them, so how to tell bunch ripeness in such palms? By incorporating the virescens gene into them! Crosses between non-shedding teneras, and a selected virescens tenera and dura, both ex-Lobe, Cameroon, were planted in 1999 in Pamol (Rao et al., 2001). Meanwhile, the pioneering work on oil palm fruit abscission by Henderson and Osborne (1990; 1994) has continued with further insights into related anatomical and biochemical changes (Henderson et al., 2001; Tranbarger, 2012; Roongsattham et al., 2016) and their genetical control (Roongsattham et al., 2012; Fooyontphanich et al., 2016; Tranbarger et al., 2019).

Ogbuanu et al. (2015) reported that while both nigrescens and virescens oils have similar physical properties, the latter, with an iodine value of 83.8 is closer to olive oil and likewise too its density. The peroxide value of virescens oil is also markedly higher than in nigrescens oil, as would be expected if it is less saturated. The more than double phospholipids and presence of cystine (an amino acid) are suggested to confer the medicinal and antipoison properties of virescens oil. However, there has been little corroboration of Ogbuanu et al. (2015) results, which may, therefore, be spurious. Other studies have shown the iodine values of both oils to be similar. For example, in their attempt to produce high iodine value material, the Malaysian Palm Oil Board (MPOB) screened 2400 palms from the Malaysian Agricultural Research and Development Institute (MARDI)-Nigerian Institute for Oil palm Research (NIFOR) prospection of 1973, including 
several virescens palms. The maximum iodine value from a nigrescens palm was only 69.75 (Arasu et al., 1988), while virescens Palm T128, distributed to the industry for its high iodine value, had 63.4 (Kushairi et al., 1999), not very different.

The breakdown of chlorophyll is good for palm oil as it adversely affects the oil oxidative stability, bleachability and hydrogenation. Ikemefuna and Adamson (1984), in Table 1 and Tan et al. (1997) showed that chlorophyll in palm oil decreases with ripening although never completely. As chlorophyll is removed in refining crude palm oil (CPO) for consumption, less of it in the initial oil is better. The question begged is how similar the chlorophyll breakdown processes are in both virescens and nigrescens oils, and their levels ex-palm, if virescens is to become commercial planting material.

\section{Virescens FOUNDER PALMS AND POPULATIONS - HISTORIC}

Due to their rarity and no perceived commercial advantage, at least until recently, there has been little interest in virescens breeding. However, the progenies of individual virescens palms, selected for their other traits, have been exchanged, the fruit colour but incidental. The below listing of the main virescens palms exchanged and the diaspora of their descendants is a history of the passing interest in the trait. There was some love for them but not quite the ardour of Romeo and Juliet (Shakespeare, 1597).

\section{NIFOR Virescens via Department of Agriculture of Malaya (DOAM)}

This is the most distributed virescens internationally and over the longest period. The palms, together with the early NIFOR [formerly known as the West African Institute for Oil Palm Research (WAIFOR)] breeding materials, were from 4.45 ha (11 ac) plot of about 800 palms in Calabar, Eastern Nigeria, planted in 1912-1916 from a small number of open pollinated bunches of various types and forms, including mantled and virescens. Each type and form was represented by seeds from a single parent. Hence, the occurrence of both tenera and dura virescens in a particular progeny suggests that the parent was a tenera virescens. Yield and bunch data were collected from 1922-1928, and among the nine duras selected for performance, two were virescens - CA551.341 and CA551.375. Broekmans (1957) provided data on all nine, reproduced in Table 2 with the two virescens highlighted. Hartley (1988) mentioned that, besides the two virescens duras, some tenera virescens were also selected (as seed parents). Specific information on the virescens teneras is, unfortunately, not available, but the mean performance of all the 10 selected teneras (from 43 teneras - 36 nigrescens and seven virescens) gives an idea of the quality of the NIFOR virescens teneras (last row in Table 2). In other words, as the selection was based on performance per se, the virescens teneras were unlikely to be very different from the overall mean.

The NIFOR virescens arrived in Malaya in the early $20^{\text {th }}$ century, at a time of increasing interest in oil palm. The first virescens in Malaya was probably from the 1926-1927 introduction by DOAM - 28 palms from "... no less than 40 different lots of seeds from the various palm oil producing countries in West Africa." - established in a ha (1 ac) plot at the Central (later Federal) Experiment Station, Serdang (Bunting et al., 1927; 1934). They recorded that among the more distinct types was E. guineensis var. rapanda Chev. with fruits that were a "... vivid cypress-green in the early stages of development changing when ripe to a deep orange.". This plot, Field 19, included the fertile pisiferas - 29/36 and $36 / 21$ - used by DOAM to produce its early DxP planting materials. Given that Malaya and the then British West African countries were fellow British colonies, most oil palm materials came to Malaya through this channel. Thus, early Malayan virescens were highly likely to be of NIFOR origin.

The analysis of 100 ripe rapanda fruits, presumably from the same bunch, in comparison to the then average Malayan fruit, which was Deli dura, are given in Table 3 (from Bunting et al., 1934). The constituents, in percentage, suggest that the rapanda, or virescens fruits were tenera, not atypical of the 'wild' teneras in Africa. They had a fresh mesocarp content of $\sim 68 \%$. The $\%$ shell and $\%$ kernel were high compared to modern teneras, but lower than in dura then and now.

From this African/NIFOR introduction, a selected virescens tenera was crossed to fertile pisifera 29.36 from the previously-mentioned Field 19 , and twice to a selected virescens tenera from the nearby Highlands Estate (HE). These three virescens families, together with another seven miscellaneous TxT families, were planted in Trial 0.126 at the Federal Experiment Station (FES) Serdang in 1969. We have no record of the HE virescens palm but, given that most of the early materials at HE were from FES Serdang, it may have been a descendant of the Field 19 virescens. A cross of the HE virescens with Serdang fertile pisifera 29.36 was provided to Federal Land Development Authority (Felda), later transferred to Felda Global Ventures (FGV), when they started their breeding programme, the cross coded as progeny 'RM'. The only other early virescens in the country then, from records we have sighted, was an Ulu Remis virescens which is described in the next section. Gray and Bevan (1966) mentioned that virescens was quite rare in Malaya and that there was no commercial interest in it. 
TABLE 1. REDUCTION IN CHLOROPHYLL CONTENT (mg kg-1) IN OIL OF RIPENING Nigrescens FRUIT*

\begin{tabular}{|c|c|c|c|c|c|c|c|}
\hline \multirow{3}{*}{ Pigment } & Fruit type & \multicolumn{3}{|c|}{ Tenera } & \multicolumn{3}{|c|}{ Dura } \\
\hline & Ripeness & Green & Mature & Ripe & Green & Mature & Ripe \\
\hline & Age (months) & $1-2$ & $3-4$ & $5-6$ & $1-2$ & $3-4$ & $5-6$ \\
\hline Chlorophyll a & & 28.9 & 20.7 & 4.3 & 26.5 & 22.7 & 2.4 \\
\hline Chlorophyll b & & 18.6 & 15.3 & 7.3 & 19 & 11.8 & 4.6 \\
\hline
\end{tabular}

Source: * Ikemefuna and Adamson (1984).

TABLE 2. QUALITY OF NIFOR Duras SELECTED FOR PERFORMANCE, INCLUDING TWO Virescens, AND OF Teneras INCLUDING SOME Virescens

\begin{tabular}{|c|c|c|c|c|c|c|c|}
\hline Parent palm & $\underset{\left(\mathrm{kg} \mathrm{yr}^{-1)}\right.}{\mathrm{FFB}}$ & $\begin{array}{l}\text { FB } \\
(\%)\end{array}$ & $\begin{array}{l}\text { MF } \\
(\%)\end{array}$ & $\begin{array}{c}\text { LOSS } \\
(\%)\end{array}$ & $\begin{array}{l}\text { SF } \\
(\%)\end{array}$ & $\begin{array}{l}\text { KF } \\
(\%)\end{array}$ & $\begin{array}{l}\text { FWT } \\
(\%)\end{array}$ \\
\hline \multicolumn{8}{|l|}{ Dura } \\
\hline 551.141 & 64.9 & 78.3 & 46.2 & 3.4 & 32.9 & 17.5 & 11.3 \\
\hline 551.222 & 75.7 & 70.8 & 52.4 & 3.4 & 32.1 & 11.9 & 8.2 \\
\hline 551.224 & 77.1 & 67.9 & 43.9 & 3.1 & 39.1 & 13.9 & 8.6 \\
\hline 551.233 & 90.7 & 58.7 & 48.2 & 2.9 & 34.8 & 14.1 & 4.5 \\
\hline 551.256 & 114.3 & 64.7 & 52.5 & 2.7 & 30.4 & 14.4 & 9.1 \\
\hline 551.341 & 82.6 & 67.8 & 49.3 & 4.4 & 32.7 & 13.6 & 12.2 \\
\hline 551.375 & 139.3 & 63.4 & 44.2 & 4.7 & 38.7 & 12.4 & 6.4 \\
\hline 551.703 & 112.5 & 72.8 & 43.8 & 3.4 & 40.0 & 12.8 & 10.9 \\
\hline 551.261 & 61.2 & 68.6 & 62.6 & 2.1 & 22.2 & 13.0 & 11.3 \\
\hline \multicolumn{8}{|c|}{ Tenera (including virescens) } \\
\hline Avg & 67.0 & 56.0 & 64.0 & - & 18.0 & 10.0 & - \\
\hline
\end{tabular}

Note: FFB - fresh fruit bunch yield in $\mathrm{kg} \mathrm{palm}^{-1} \mathrm{yr}^{-1}, \mathrm{FB}-\%$ fruit in bunch, MF - \% mesocarp in fruit, LOSS - \% material loss during analysis, SF - \% shell in fruit, KF - \% kernel in fruit, all \% on fresh weights, FWT - mean fruit weight.

Source: Broekmans (1957.)

TABLE 3. COMPARISON OF AVERAGE MALAYAN OIL PALM FRUIT (Deli Dura) AND RAPANDA TYPE (Virescens) Tenera* IN 1930s

\begin{tabular}{lcc}
\hline Constituent & $\begin{array}{c}\text { Average } \\
\text { Malayan fruit }\end{array}$ & Rapanda type \\
\hline Palm oil & 29.0 & 32.0 \\
Palm kernel & 6.0 & 9.0 \\
Shell & 30.0 & 23.0 \\
Moisture and residue & 35.0 & 36.0 \\
\hline
\end{tabular}

Note: *Bunting et al. (1934). All figures are \% of fresh fruit weight.

The third generation (with the original virescens in Africa as the first) virescens comprised selected palms from Trial 0.126, sib-mated and planted in Trial 0.261 at Bukit Lawiang, Johor, Malaysia in 1990. This was undertaken by MPOB which, since its inception in 1979 as the Palm Oil Research Institute of Malaysia (PORIM), managed the oil palm trials at FES Serdang while founding new oil palm research stations. Some of the MPOB crosses were also provided to Eastern Plantation Agency (EPA), which had then just started oil palm breeding (Rao and Musa, 1995), and planted in Trial 9105.09 at Ladang Tereh Selatan (LTS) estate. The MPOB crosses may still be extant but the EPA trials have probably been replanted. Figure 3 shows the descent, from 1920s-1990s, of the first virescens that entered Malaya/Malaysia. 


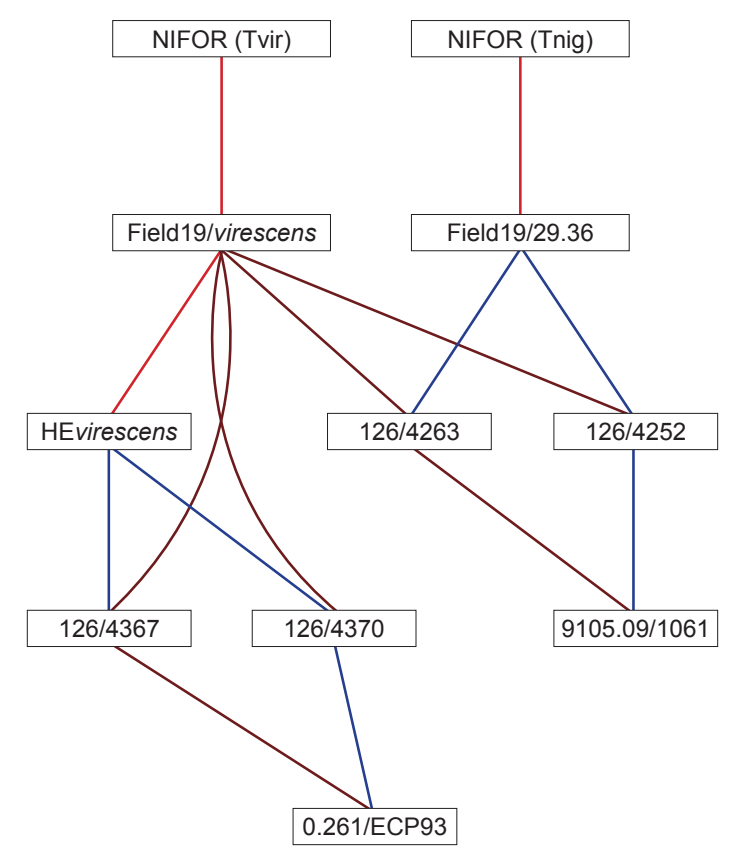

Note: NIFOR - Nigerian Institute for Oil Palm Research. HE - Highlands Estate.

Figure 3. Lineage of ex-NIFOR Serdang virescens, 1920-1990.

\section{Via IRHO/CIRAD}

As mentioned above, Felda/FGV received NIFOR virescens through DOAM in the late 1960s. Some five years later, more NIFOR virescens were received from the Institut de Recherches pour les Huiles et Oleagineux (IRHO) [now Centre de Coopération Internationale en Recherche Agronomique pour le Développment (CIRAD)] from their stations in Pobe, Benin and $\mathrm{La} \mathrm{Me}$ in Ivory Coast. There were eight crosses, two between virescens palms and the rest nigrescens $\mathrm{x}$ virescens.

United Plantations Berhad (UPB) planted two virescens progenies in 1977. The first (TT69) was an early Deli dura (ex-Marihat Baris) crossed to a Yocoboue selection from IRHO with the virescens probably the latter. The other progeny (TT80) was derived from an ex-NIFOR virescens tenera with IRHO code WA10. Teneras and pisiferas from TT69 and TT80 are prominent in UPB's subsequent crosses but virescens individuals rare. A selected palm (virescens) from TT69 was crossed to a selected palm from TT1 (L239TxL432T) and the progeny (TT132) planted in 1992.

\section{Ulu Remis Virescens}

The second batch of virescens distributed was among the first oil palms planted at Ulu Remis Estate, Johor. They were open-pollinated seeds from Sumatra, believed to be from Marihat Baris Estate (Rosenquist, 1999). While the Marihat breeding programme then focussed on breeding only the Deli dura type (all nigrescens), imported African seeds were also planted around 1920 (Janssen, 1959). Hence, while it is possible that the Ulu Remis seeds came from yield-recorded Deli palms, the fact that they were open-pollinated suggests the virescens to be Nigrescens ${ }_{\text {Deli }} \mathrm{x}$ Virescens ${ }_{\text {African }}$. Nevertheless, the possibility of it being a Deli dura mutation from nigrescens to virescens cannot be dismissed. The virescens was among 175 selected, with FFB $>200 \mathrm{~kg}$ $\mathrm{yr}^{-1}$, as parents for commercial seed production and further breeding. The palms were labelled ' $\mathrm{PP}$ ' and the virescens was PP201.

A self of PP201 was planted in Trial GB4B in 1940 (and as supplies in Trial GB1A). The self was UR258 and, 20 years later, two virescens palms (UR258/1 and UR258/2) were selected from this family to create virescens UR672 and 673, the first a sib cross and the second an outcross to a nigrescens (UR120/2). Besides planting in Ulu Remis (Trial GB19B), UR672 was provided to UPB and Société Financière des Caoutchoucs (SOCFIN) (coded SOC2739). The cross was planted in 1959/1960 at these three locations but no resulting virescens palms seemed to have been selected for further use.

\section{Virescens FOUNDER PALMS AND POPULATIONS - RECENT}

All the recent virescens palms in Malaysia came from germplasm collected in the 1970s and 1980s. Virescens was encountered in most of the countries prospected, and collected if ripe bunches were available. From these open pollinated collections, heterozygous for the trait, a few individuals were selected for breeding, although not for their virescens. The unselected virescens have since been discarded.

\section{Palm 0.151/128T and Discovery of the Virescens Gene}

The most disseminated and tested recent virescens palms are all from the MARDI-NIFOR prospections in 1973. The 1973 prospection in Nigeria was not only the most systematic search but its provenances also the best reconnoitred. The germplasm was planted at the MARDI station in Kluang, Johor between 1975-1976 and handed over to MPOB in 1979. Crosses from three virescens palms, from that germplasm, have been distributed to the industry but, again, not for their virescens. Of them, $0.151 / 128 \mathrm{~T}$ is the most disseminated and tested.

Oil (un)saturation was the rage in the 1980s, for the now debunked coronary health reasons, and for a more liquid palm oil. The existing germplasm was obviously the best place to search. Trial 0.151 at MPOB Kluang, with palms from the 1973 Nigerian prospection, was a good starting point. Of the $\sim 2400$ palms screened, 13 had iodine value $>61$ compared 
to $\sim 55$ of commercial materials. Of them, only $151 / 128 \mathrm{~T}$ was tenera (the rest duras as the prospection had focussed on dura), and it was also high yielding and virescens. Table 4 shows some of its performance data as well as those of the population from which it came. Table 5 shows the fatty acid composition of its oil, the primary reason for its selection. The palm was an open pollinated offspring from a dura virescens bunch from Ufuma, Nigeria. Like much of the prospected materials, the fruits were small, a mere $5 \mathrm{~g}$, with $46 \%$ mesocarp (field notes from 1973 MARDI-NIFOR prospection in Nigeria).

Selfs of the palm and its pollen were provided to several companies interested in breeding for a less saturated oil, besides being planted in MPOB itself. It was this combined large population of $0.151 / \mathrm{T} 128 \mathrm{~T}$ offspring, segregating for nigrescens and virescens, that helped in the discovery of the virescens gene.

UPB was upfront in the breeding for less saturated oil, hence, their interest in $0.151 / 128 \mathrm{~T}$, not for its virescens. The other high iodine value selections acquired by UPB from MPOB were all duras and nigrescens. Besides the selfing of
$0.151 / 128 \mathrm{~T}$, it was also crossed to 10 UPB high iodine value teneras, three pisiferas from high iodine value families, an oleifera and oleifera-guineensis hybrid. Sharma (1999; 2003) presented their performance (including iodine value), followed by an update by Musa and Gurmit (2008) for the E. guineensis crosses (Table 6). The selfs retained the high iodine value of their parent and the small fruits and bunches, but the oil yields were low. Outcrossing with UPB high iodine value selections improved the fruit and bunch size but with still low oil yields and some diminution in the iodine value. The values for the crosses with the Oleifera-guineensis hybrid and an Oleifera-guineensis x guineensis backcross were typical for such crosses with no additional value conferred by the high iodine value $0.151 / 128 \mathrm{~T}$. Nevertheless, a few individuals with oil yield comparable to that of commercial DxP were identified for cloning.

Like most, if not all virescens, $0.151 / 128 \mathrm{~T}$ was heterozygous for the trait and its selfs and outcrosses segregated into nigrescens and virescens. Three palms from the selfs and one from an outcross were selected for further crossing and their descendants shown in

TABLE 4. PERFORMANCE OF PALM 0.151/128T AND ITS BACKGROUND POPULATION

\begin{tabular}{lccccccccc}
\hline Pop or palm & FFB & BN & BW & FW & FB & MF & OM & OB & KB \\
\hline Pop 14 (T) & 174.4 & 16.6 & 11.4 & 6.8 & 69.4 & 80.8 & 50.9 & 26.5 & 5.5 \\
Pop 14(D) & 166.3 & 15.4 & 12.3 & 9.6 & 64.6 & 49.6 & 48.4 & 15.6 & 7.6 \\
Palm 0.151/128T & 217.2 & 22.3 & 10.3 & 7.2 & 67.5 & 80.8 & 50.0 & 27.2 & 4.9 \\
\hline
\end{tabular}

Note: FFB - fresh fruit bunch yield in $\mathrm{kg} \mathrm{palm}^{-1} \mathrm{yr}^{-1}, \mathrm{BN}$ and $\mathrm{BW}$ - average number of bunches produced/year over the period of recording and their average weight $(\mathrm{kg}), \mathrm{FW}$ - mean fruit weight $(\mathrm{g}), \mathrm{FB}-\%$ fruit in bunch, MF - \% mesocarp in fruit, OM - \% oil in mesocarp, $\mathrm{OB}$ and $\mathrm{KB}-$ oil and kernel content $(\%)$ of fruit bunches, all \% on fresh weights.

TABLE 5. FATTY ACID COMPOSITION (in \%) OF PALM OIL FROM Virescens PALMS 0.151/128T AND 0.151/618D

\begin{tabular}{lcccccc}
\hline Palm & C14:0 & C16:0 & C18:0 & C18:1 & C18:2 & I.V. \\
\hline $0.151 / 128 \mathrm{~T}$ & 0.6 & 35.3 & 5.3 & 42.1 & 15.8 & 63.4 \\
$0.151 / 618 \mathrm{D}$ & 0.6 & 33.7 & 6.7 & 44.2 & 13.5 & 61.2 \\
\hline
\end{tabular}

Note: IV - iodine value.

TABLE 6. PERFORMANCE OF MPOB Virescens 0.151/128T CROSSES AT UNITED PLANTATIONS BERHAD*

\begin{tabular}{lccccccccc}
\hline Cross & FFB & BN & BW & FW & MF & SF & OB & KB & HI \\
\hline 0.151/128T self & 196.0 & 28.8 & 5.4 & 6.7 & 78.5 & 13.7 & 21.5 & 4.5 & 0.56 \\
TT29/64x0.151/128T & 240.0 & 26.6 & 9.0 & 10.5 & 82.9 & 9.0 & 25.9 & 6.4 & 0.49 \\
TP6/328x0.151/128T & 241.3 & 27.9 & 8.6 & 6.7 & 80.3 & 11.1 & 23.5 & 6.0 & 0.53 \\
TT10/843×0.151/128T & 237.5 & 27.0 & 8.8 & 7.2 & 76.8 & 12.1 & 22.9 & 4.9 & 0.46 \\
TT10/867x0.151/128T & 209.0 & 30.5 & 6.9 & 7.7 & 76.3 & 13.8 & 21.5 & 4.9 & 0.45 \\
Standard DP cross & 246.5 & 21.6 & 14.8 & 12.9 & 82.4 & 8.8 & 26.8 & 5.4 & 0.61 \\
\hline
\end{tabular}

Note: FFB - fresh fruit bunch yield in $\mathrm{kg} \mathrm{palm}^{-1} \mathrm{yr}^{-1}, \mathrm{BN}$ and BW - average number of bunches produced/year over the period of recording and their average weight $(\mathrm{kg}), \mathrm{FW}$ - mean fruit weight $(\mathrm{g}), \mathrm{MF}-\%$ mesocarp in fruit, SF - \% shell in fruit, OB and KB - oil and kernel content $(\%)$ of fruit bunches, all \% on fresh weights, $\mathrm{HI}$ - height increment in $\mathrm{cm} \mathrm{yr}^{-1}$.

Source: *Musa and Gurmit (2008). 
Figure 4. We are not aware if any of the selections were virescens and, hence, whether the virescens trait was continued. Note that if the WA10 origin (a NIFOR virescens) provided to UPB by IRHO, and its descendant, TT80/45T, as well as TT113/320T from the self of 151/128T, are both virescens, then the cross (TT209) would have had both homozygous and heterozygous virescens palms. Also, the virescens trait in the case would have come from both ancestors, and if the ancestral virescens were from different mutations, then the 'homozygosity' would be due to two different Vir alleles and not $2 x$ the same one. While probably of no practical importance, this 'different homozygosity' is godsend for studying the trait genotype-phenotype relationship. A caveat, however, is that Singh et al. (2014) found all five virescens from the Nigerian germplasm to have the same mutation and the above ancestral virescens are from West Africa / Nigeria.

Felda/FGV took the selfs of $0.151 / 128 \mathrm{~T}$ and its pollen and used the latter to cross with two Yangambi and one Yangambi-La Me selected teneras. The pollen was also used in progeny test combinations with a range of Deli duras. An outstanding tenera (B36/35T) from a Yangambi cross was extensively progeny tested and used to create new materials with Felda's/FGV's other tenera/pisifera populations. A sib dura (B36/36D) was progeny tested with Yangambi and AVROS pisiferas, the crossings illustrated in Figure 4. Besides the above extensive work, Felda /FGV also collected a self of another virescens from the MPOB Nigerian collection, high iodine value virescens dura 0.151 / 618D (Table 5), as well as a self of a virescens dura $(0.221 / 1362 \mathrm{D})$ from the MPOB Congo collection. These origins, however, were not exploited further.
During this time of active virescens breeding several virescens teneras, of NIFOR and $0.151 / 128 \mathrm{~T}$ origins, were cloned and planted in trials, but not released for commercial planting.

Following their initial, albeit incidental, collection of virescens and subsequent extensive work with the Nigerian Prospected Material (NPM) virescens, as well as crossings with their advanced Yangambi families, Felda registered two virescens 'varieties' in 2009 - Felda Tenera Yangambi Virescence and Felda Dura Yangambi Virescence - for protection. Despite Felda/FGV having produced pure virescens $\mathrm{DxP}$, there has been no commercial release possibly because their performance is only comparable to that of commercial nigrescens DxP. The industry would need more incentive, for example, much higher yields, to depart from their tried and trusted nigrescens.

Applied Agricultural Resources (AAR) included 151/128T in their NPM testing with their advanced dura and tenera/pisifera parents (Soh et al., 1999). The palm had good combining ability for high bunch number, high oil/bunch, low height and low frond dry weight. The high iodine value was reflected by high C18:1. However, the work has been discontinued.

The third virescens NPM designated for the next generation is $0.150 / 501 T$. This is a tenera from Population 12, high yielding and very short, and hence with a high bunch index as well as having oil with high vitamin E (Kushairi, 1999). Selfs were provided to an industry member besides planting in MPOB. The selfs segregated in the expected ratios for a heterozygous virescens and were dwarf, but otherwise poor in yield and bunch characters (Kalaimugilan, 2020).

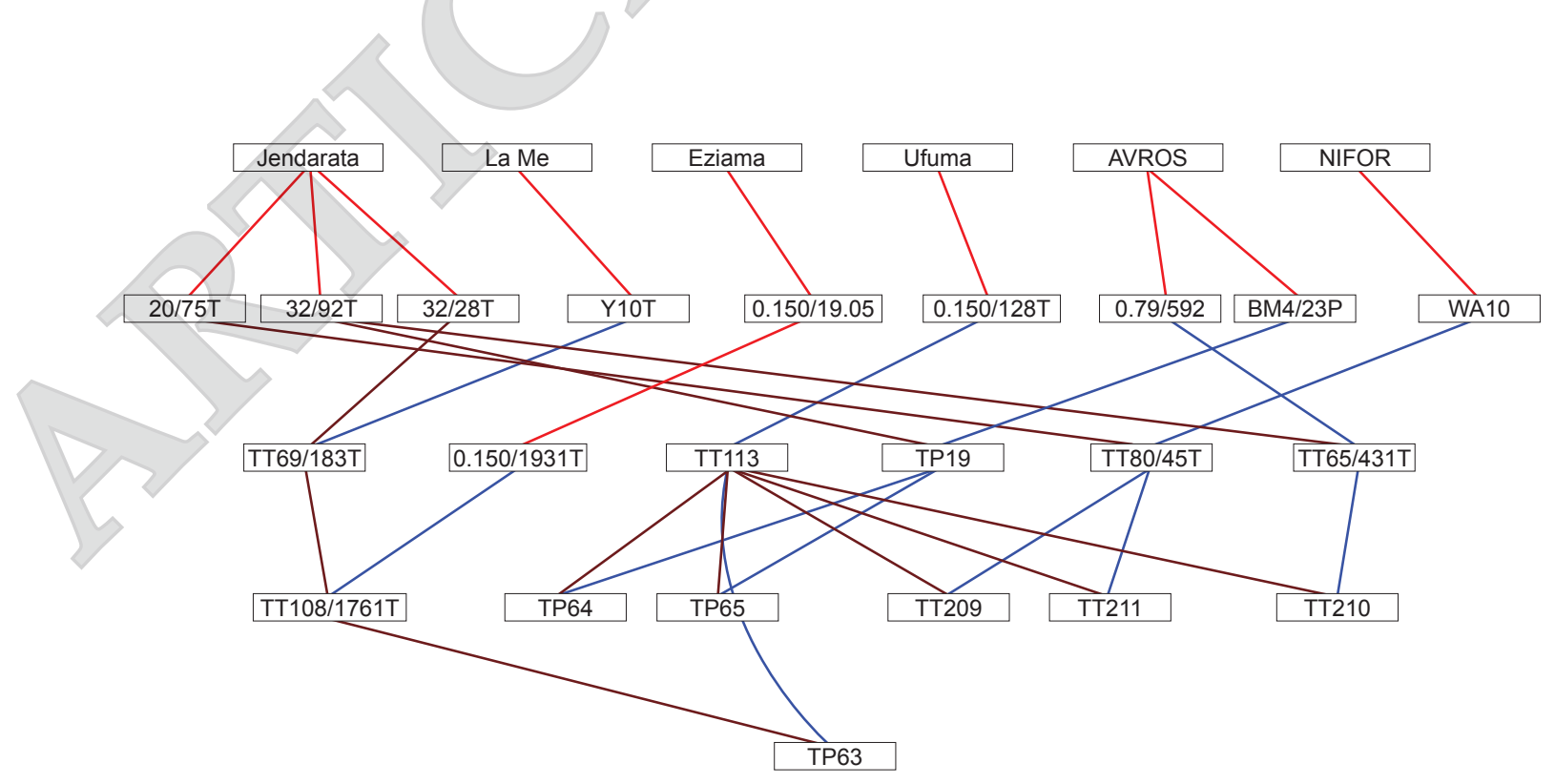

Figure 4. Origins of some high iodine value crosses at the United Plantations Bhd (UPB) including virescens MPOB 0.151/128T and NIFOR/CIRAD WA10. 


\section{Angola Virescens}

The most recent germplasm collection is the 2010 joint prospection by Indonesia, Malaysia and Instituto Nacional do Café de Angola (INCA) in Angola. This was on top of a 1991 limited prospection by MPOB/INCA in the same country. The Angola palms have large fruits and thick mesocarp, in clear contrast to the small poor-quality fruits of other collections, the main stumbling block to their wider use in breeding (Table 7).

Adon et al. (1998) showed the successful introgression of the Angola germplasm in the IRHO/CIRAD breeding programme. The work offers hope out of the Deli dura genetic bottle-neck, the raison d'etre for prospection for oil palm diversity in the centres of origin. Furthermore, their (Angola germplasm) tolerance to vascular wilt suggests possible tolerance also to Ganoderma, the scourge of oil palm in South-east Asia.

Following evaluation of its prospected materials, MPOB have disseminated progenies of the best palms to all the major breeding programmes in the country. The average performance of the dura and tenera palms from the prospections and a selected virescens palm provided to the industry is shown in Table 8.

In Indonesia, seedlings from the 2010 prospection have been shared with the sponsors of the expedition - the major oil palm breeding organisations - and the materials, which include good numbers of virescens progenies, are being field trialled.

Interestingly, unlike in the Nigerian germplasm, virescens Angola palms could be due to one of three mutant alleles, two point mutations and a deletion (Singh, 2014). The difference could be studied for further insight into the trait genotype-phenotype relationship.

\section{CONCLUSION}

The common oil palm is the nigrescens type which immature fruit is dark violet, ripening to red with violet tinges, following the degradation of anthocyanins, other flavonoids and chlorophyll in the epicarp as carotene accumulates in the mesocarp. The rarer virescens lacks anthocyanins and flavonoids, but chlorophyll gives the immature fruit a bright green colour. On ripening, the chlorophyll degrades, and carotenes also accumulate in the mesocarp, making the fruit a bright orange. Virescens is due to rare mutations of the Vir gene, which make it possible to breed for. The trait is a more obvious cue of fruit ripeness to harvest than nigrescens, especially for tall palms, and for grading FFB for milling. It is a vital trait to introgress into non fruit-abscinding oil palm to ascertain when to harvest the ripe bunches which do not shed fruits. Besides employing the newlydiscovered genotyping tools for breeding efficiency

TABLE 7. CHARACTERISTICS OF OIL PALM BUNCHES COLLECTED FROM ANGOLA AND OTHER WEST AFRICAN COUNTRIES (all on fresh basis)*

\begin{tabular}{lcccccc}
\hline Country & $\begin{array}{c}\text { Bunch wt } \\
\mathbf{( k g}\end{array}$ & $\begin{array}{c}\text { Single fruit } \\
\mathbf{w t}(\mathbf{g})\end{array}$ & $\begin{array}{c}\text { Mesocarp } \\
(\mathbf{\%})\end{array}$ & $\begin{array}{c}\text { Bunch wt } \\
\mathbf{( k g )}\end{array}$ & $\begin{array}{c}\text { Single fruit wt } \\
(\mathbf{g})\end{array}$ & $\begin{array}{c}\text { Mesocarp } \\
(\mathbf{\%})\end{array}$ \\
\hline Ivory Coast & 10.9 & 6.9 & 41.8 & 9.8 & 5.8 & 61.2 \\
Nigeria & 11.8 & 9.0 & 47.3 & 10.9 & 6.5 & 70.9 \\
Cameroons & 16.8 & 10.3 & 39.7 & 17.3 & 8.6 & 62.4 \\
Zaire & 17.6 & 14.2 & 43.9 & 17.4 & 12.6 & 64.1 \\
Angola & 21.4 & 14.2 & 48.9 & 16 & 11.7 & 70.9 \\
\hline
\end{tabular}

Note: wt - weight.

Source: *Rajanaidu (1991).

TABLE 8. MEAN PERFORMANCE OF Duras AND Teneras IN MPOB'S 1991 ANGOLA PROSPECTIONS AND OF A SELECTED Virescens PALM (P0.312/1263T)*

\begin{tabular}{lccccccccccc}
\hline & FFB & BN & BW & FB & FW & MF & SF & ODM & OB & KB & HI \\
\hline $0.312 /$ Dura & 144.4 & 14.0 & 10.7 & 65.0 & 12.5 & 49.9 & 38.7 & 77.0 & 15.0 & 7.4 & 0.4 \\
$0.312 /$ Tenera & 158.6 & 14.3 & 11.4 & 63.1 & 11.0 & 74.3 & 14.2 & 77.4 & 21.9 & 7.3 & 0.5 \\
0.312 1263T $_{\text {vir }}$ & 227.9 & 16.4 & 14.1 & 68.2 & 13.7 & 72.3 & 13.9 & 79.5 & 23.9 & 9.4 & 0.8 \\
\hline
\end{tabular}

Note: FFB - fresh fruit bunch yield in $\mathrm{kg}_{\text {palm }}^{-1} \mathrm{yr}^{-1}, \mathrm{BN}$ and BW - average number of bunches produced / year over the period of recording and their average weight $(\mathrm{kg}), \mathrm{FB}-\%$ fruit in bunch, FW - mean fruit weight (g), MF - \% mesocarp in fruit, SF - \% shell in fruit, ODM - \% oil in dry mesocarp, OB and KB - oil and kernel content $(\%)$ of fruit bunches, all \% on fresh weights, HI - height increment in $\mathrm{cm} \mathrm{yr}^{-1}$. 
gain, starting with the right genetic stocks will shorten the process of achievement. The virescens palms from recent germplasm collections in Angola are a promising start. Discovery of the virescens gene plus the now widespread trialling of new virescens palms, in both Indonesia and Malaysia, may be key to staving off the threats to oil palm - laborious harvesting and fruit collection in the increasingly worker-short industry.

\section{ACKNOWLEDGEMENT}

The authors would like to thank Kysnadyana for inspiring the write-up and completion of this review article.

\section{REFERENCES}

Abdullah, M Z; Guan L C; Mohd-Azemi, B M N (2001). Stepwise discriminate analysis for colour grading of oil palm using machine vision system. Food Bioprod. Proc., 79: 223-231.

Adon, B; Baudouin, L; Durrand Gasselin, T and Kouame, B (1998). Utilisation de material non ameliore pour la selection du palmier a huile: l'origine Angola. Plantations, Recherche, Development (Mei-Jun): 201-205.

Akpo, E; Vissoh, P V; Tossou, R C; Crane, T; Kossou, D K; Richards, P; Stomph, T J and Struik, P C (2012). A participatory diagnostic study of the oil palm (Elaeis guineensis) seed system in Benin. NJASWageningen J. Life Sciences (60-63): 15-27.

Alfatni, M S M; Shariff, A R M; Shafri, H Z M; Saaed,' O M B and Eshanta, O M (2008). Oil palm fruit grading system using red, green and blue digital number. J. Applied Sciences, 8(8): 1444-1452.

Alfatni, M S M; Shariff, A R M; Abdullah, M Z; Marhaban, M H; Shafie, S B; Amiruddin, M D and Saaed, O M B (2014). Oil palm fresh fruit bunch ripeness classification based on rule- based expert system of ROI image processing technique results. IOP Conference Series: Earth and Environmental Science Vol. 20: 012018.

Arasu, N T; Lawrence, M J and Rajanaidu, N (1988). Prospects for the alteration of fatty acid composition in the oil palm through breeding. Proc. of the 1987 Int. O.P./P.O. Conf. - Agriculture. PORIM, Bangi. p. 86-93.

Beirnaert, A and Vanderweyen, R (1941). Contribution à l'étude génétique et biométrique des variétés d'Elaeis guineensis Jacquin. Publications de 1'Institut National pour l'Étude Agronomique, Série Scientifique 27. Belgian Congo.

Bensaeed, O M; Shariff, A R M; Mahmud, A B; Shafri, $\mathrm{H}$ and Alfatni, M (2014). Oil palm fruit grading using a hyperspectral device and machine learning algorithm. IOP Conference Series: Earth and Environmental Science Vol. 20: 012017.

Broekmans, A F M (1957). The production of improved oil palm seed in Nigeria. J. West Afr. Inst. Oil Palm Res., 2: 116-132.

Bunting, B; Eaton, B J and Georgi, C D V (1927). The oil palm in Malaya. Department of Agriculture Bulletin No. 39. Kuala Lumpur.

Bunting, B; Georgi, C D V and Milsum, J N (1934). The oil palm in Malaya. Department of Agriculture Malayan Planting Manual No. 1.

Cherie, D; Herodian, S; Ahmad, U; Mandang, T and Makky, M (2015). Optical characteristics of oil palm fresh fruits bunch (FFB) under three spectrum regions. Influence for Harvest Decision Vol. 5 No. 3: 255.

Donough, C R; Corley, R H V and Law, I H (1995). 'Non-shedding' variants of the oil palm. ISOPB Newsletter, 11(2): 10-11.

Ergo, A B (1997). Nouvelle evidence de l'origine Africaine de l'Elaeis guineensis Jacq. Par la découverte de graines fossils en Uganda. Annales de Gembloux, 102: 191-201.

Eziokwu Chineke Gadi (2017). Eziokwu Chineke Gadi Traditional Outreach. https://web. facebook.com / 120520055335816/ posts / aboutakw \% E1\%BB\% A5-\%E1\%BB\%8Djukwu-red-palmfruitthis-palm-fruit-is-called-akw $\%$ E1\% BB $\%$ A5ojukwu-in-my-dial / 124834908237664 / ?_rdc=1\&_ rdr, accessed on 8 January 2019.

Fooyontphanich, K; Morcillo, F; Amblard, P; Collin, M; Jantasuriyarat, C; Verdeil J-L; Tangphatsornruang, S and Tranbarger, T J (2016). A phenotypic test for delay of abscission and non-abscission oil palm fruit and validation by abscission marker gene expression analysis. Acta Horticulturae, 1119: 97-104. http://dx.doi. org / 10.17660 / ActaHortic.2016.1119.13

Gray, B S and Bevan, J W L (1966). Chapter 2: Varieties in the oil palm in Malaya. Ministry of Agriculture and Cooperatives. 23 pp.

Hartley, C (1988). The Oil Palm. Third edition. Harlow, Essex, United Kingdom. p. 47-94. 
Hazir, M H M; Shariff, A R M and Amiruddin, M D (2012). Determination of oil palm fresh fruit bunch ripeness based on flavonoids and anthocyanin content. Industrial Crops and Products Vol. 36(1): 466475 .

Henderson, J and Osborne, D J (1990). Cell separation and anatomy of abscission in the oil palm Elaeis guineensis Jacq. J. Exptl. Bot., 41: 203-210.

Henderson, J and Osborne, D J (1994). Intertissue signalling during the 2-phase abscission in oil palm fruit. J. Exp. Bot., 45: 943-951.

Henderson, J; Davies, H A; Heyes, S J and Osborne, D J (2001). The study of a monocotyledon abscission zone using microscopic, chemical, enzymatic and solid-state C-13 CP/MAS NMR analyses. Phytochemistry, 56: 131-139.

Hortensteiner, S and Krautler, B (2011). Chlorophyll breakdown in higher plants. Biochimica et Biophysica Acta, 1807: 977-988.

Ikemefuna, J and Adamson, I (1984). Chlorophyll and carotenoid changes in ripening oil palm fruit, Elaeis guineensis. Phytochem., 23(7): 1413-1415.

Janssen, A W B (1959). Miscellaneous notes on estate agriculture in Sumatra No. 7 oil palm productivity and genetics. Chemara Research Station, Layang Layang, Johor.

Junkwon, P; Takigawa, T; Okamoto, H; Hasegawa, H; Koike, M; Sakai, K; Siruntawineti, J; Chaeychomsri, W; Vanavichit, A; Tittinuchanon, P and Bahalayaodhin, B (2009). Hyperspectral imaging for non-destructive determination of internal qualities for oil palm (Elaeis guineensis Jacq. Var. tenera). JSAI Agric. Info. Res., 18(3): 130141.

Kalaimugilan, B (2020). Personal communication. Kuala Lumpur.

Kushairi, A; Rajanaidu, N and Jalani, B S (1999). PORIM Series 2. PORIM Information Series No. 16: $2 \mathrm{pp}$.

Kushairi, A; Rajanaidu, N; Mohd Din, A; Isa, Z A; Noh, A and Junaidah, J (2004). Performance of Angola genetic materials. Proc. of the Seminar on Progress of PS1 and PS2 Planting Materials and Release of Elite Germplasm to the Industry. MPOB, Bangi. p. 75-90.

Meunier, J (1969). Etude des populations naturelles d'Elaeis guineensis Jacq. en Côte d'Ivoire. Oléagineux, 24: 195-201.
Musa, B and Gurmit, S (2008). Utilization of MPOB germplasm at United Plantations. Proc. of the $3^{\text {rd }}$ Seminar on Performance of MPOB PS1 and PS2 Materials and Elite Germplasm. p. 43.

Ogbuanu, C C; Chime, C C and Nwagu, L N (2015). Physiochemical and fatty acid analysis of virescens (Ojukwu) oil and nigrescens (ordinary) palm oil of Elaeis guineensis. African J. Food Science, 9(7): 400-405.

Rajanaidu, N (1986). The oil palm (Elaeis guineensis) collections in Africa. Proc. of the Int. Workshop on Oil Palm Germplasm and Utilisation. PORIM, Bangi.p. 5983.

Rajanaidu, N; Jalani, B S and Manual Domingos (1991). Collection of oil palm (Elaeis guineensis) germplasm in Angola. ISOPB Newsletter, 8(2): 2.

Rao, V (1987). Genetic Variation in Populations of Oil Palms (Elaeis guineensis) from Nigeria. Ph.D thesis. University of Birmingham. 272 pp.

Rao, V and Musa, B (1995). The EPA oil palm breeding programme. ISOPB Newsletter, 11(2): 1-9.

Rao, V (1998). Ripening in the virescens oil palm. Proc. of International Conference on Oil and Kernel Production in Oil Palm - A Global Perspective (Rajanaidu, N; Henson, I E and Jalani, B S eds.). PORIM, Bangi. p. 226.

Rao, V; Chua, C C; Ching, L C; Wah, T K and Wagiman, N (2001). Pamol Plantations Sdn Bhd Research Review 2001. Internal Report.

Roongsattham, P; Morcillo, F; Fooyontphanich, K; Jantasuriyarat, C: Somvong, T; Amblard, P; Collin, M; Mouille, G; Verdeil, J-L and Tranbarger, T J (2016). Cellular and pectin dynamics during abscission zone development and ripe fruit abscission of the monocot oil palm. Frontiers in Plant Science, 7: 540. DOI: 10.3389 /fpls.2016.00540.

Roongsattham, P; Morcillo, F; Jantasuriyarat, C: Pizot, M; Moussu, S: Jayaweera, D; Collin, M: González-Carranza, Z H; Amblard, P; Tregear, J W; Tranbarger, T J; Tragoonrung, S; Verdeil, J and Tranbarger, $\mathrm{T}$ J (2012). Temporal and spatial expression of polygalacturonase gene family members reveals divergent regulation during fleshy fruit ripening and abscission in the monocot species oil palm. BMC Plant Biol., 12: 150. DOI: 10.1186/14712229-12-150.

Roseleena, J; Nursuriati, J; Ahmed, J and Low, C Y (2011). Assessment of palm oil fresh fruit bunches using photogrammetric grading system. Int. Food Research J., 18(3): 999-1005. 
Rosenquist, E A (1999). Some ancestral palms and their descendants. Proc. of the Seminar Science of Oil Palm Breeding. PORIM, Bangi. p. 8-36.

Saeed, O M B; Sankaran, S; Shariff, A R M; Shafri, H Z M; Ehsani, R; Alfatni, M S and Hazir, M H M (2012). Classification of oil palm fruit bunches based on their maturity using portable four-band sensor system. Computers and Electronics in Agriculture, 82: 55-60.

Shakespeare, W (1597). Romeo and Juliet. Romantic tragedy. Quarto version.

Sharma, M (1999). Utilization of Nigerian PS1 and PS2 selections in oil palm breeding programmes at UP Bhd. Proc. of the Seminar on PS1 and PS2 Oil Palm Planting Materials. PORIM, Bangi. p. 18-29.

Sharma, M (2003). Utilization of PS1 and PS2 breeding materials at UP Bhd. Proc. of the Seminar on Progress of PS1 and PS2 Oil Palm Planting Materials and Release of Elite Germplasm to the Industry. MPOB, Bangi. p. 27-47.

Singh, R; Ong-Abdullah, M; Low, E T L; Manaf, M A A; Rosli, R; Nookiah, R; Ooi L C; Ooi, S E; Chan K L; Halim, M A; Azizi, N; Nagappan, J; Bacher, B; Lakey, N; Smith, S W; He, D; Hogan, M; Budiman, M A; Lee, E K; DeSalle, R; Kudrna, D; Goicoechea, J L; Wing, R A; Wilson, R K; Fulton R S; Ordway, J M; Martienssen, R A and Sambanthamurthi, R (2013). Oil palm genome sequence reveals divergence of interfertile species in Old and New Worlds. Nature, 500: 335-339. http://dx.doi.org/10.1038/ nature12309

Singh, R; Low, E T L; Ooi, L C; Ong-Abdullah, M; Nookiah, R; Ting, N C; Marjuni, M; Chan, P L; Ithnin, M; Manaf, M A A; Nagappan, J; Chan, K L; Rosli, R; Halim, M A; Azizi, N; Budiman, M A;
Lakey, N; Bacher, B; Brunt, A V; Wang, C; Hogan, M; He, D; Macdonald, J D; Smith, S W; Ordway, J M; Martienssen, R A and Sambanthamurthi, R (2014). The oil palm virescens gene controls fruit colour and encodes a R2R3-MYB. Nature Communications, 5: 4106. DOI: $10.1038 /$ ncoms5106..

Soh, A C; Rajanaidu, N; Hor, T Y and Gan, H H (1999). Combining abilities of selected parents of PORIM's Nigerian oil palm prospection in introgressed progenies with AAR's advanced breeding parents. Proc. of the Seminar on PS1 and PS2 Oil Palm Planting Materials. PORIM, Bangi. p. 30-53.

Tan, Y A; Chong, C L and Low, K S (1997). Crude palm oil characteristics and chlorophyll content. J. Sci. Food Agric., 75: 281-288.

Tan, Y A; Low, K W; Lee, C K and Low, K S (2010). Imaging technique for quantification of oil palm fruit ripeness and oil content. Euro. J. Lipid Science and Technology, 112(8): 838-843.

Tranbarger, T J (2012). Temporal and spatial expression of polygalacturonase gene family members reveals divergent regulation during fleshy fruit ripening and abscission in the monocot species oil palm. BMC Plant Biology, 12: 150. DOI: 10.1186/1471-2229-12-150.

Tranbarger, T J; Domonhédo, H; Cazemajor, M; Dubreuil, C; Fischer, U and Morcillo, F (2019). The PIP peptide of inflorescence deficient in abscission enhances Populus leaf and Elaeis guineensis fruit abscission. Plants, 8(6): 143.

Utom, S L; Mohamad, E J; Ameran, H L M; Kadir, H A; Muji, S Z M; Rahim, R A and Pusppanathan, J (2018). Non-destructive oil palm fresh fruit bunch (FFB) grading technique using optical sensor. Int. J. Integrated Engineering, 10(1): 35-39. 